Revista Brasileira de Engenharia Agrícola e Ambiental

Brazilian Journal of Agricultural and Environmental Engineering

v.25, n.4, p.250-255, 2021

agriambi

Campina Grande, PB - http://www.agriambi.com.br - http://www.scielo.br/rbeaa

DOI: http://dx.doi.org/10.1590/1807-1929/agriambi.v25n4p250-255

\title{
Soil organic carbon in no-tillage systems of different ages in Southwest Mato Grosso, Brazil ${ }^{1}$
}

\author{
Carbono em solos sob plantio direto de diferentes idades \\ no sudoeste de Mato Grosso, Brasil
}

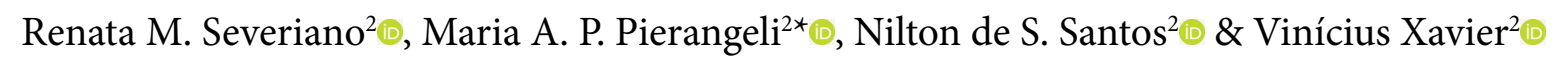

${ }^{1}$ Research developed at Pontes e Lacerda, MT, Brazil

${ }^{2}$ Universidade do Estado de Mato Grosso/Departamento de Zootecnia. Pontes e Lacerda, MG, Brazil

\begin{abstract}
HIGHLIGHTS:
Soil organic carbon (SOC) decreases up to 8 years of no-tillage systems (NT).

Soil organic carbon increased at 10 years of no-tillage systems.

At 12 years of NT $275 \mathrm{Mg} \mathrm{ha}^{-1}$ of SOC were stored up to $1 \mathrm{~m}$ depth.
\end{abstract}

\begin{abstract}
The objectives of this study were to evaluate the effect of the no-tillage system on soil bulk density, soil organic carbon, and carbon stocks in Plinthic subgroups and Oxisols, located in Pontes and Lacerda, State of Mato Grosso, Brazil. The treatments were native vegetation and no-tillage systems established for 3, 8, 10, and 12 years. To analyse soil organic carbon, soils were sampled in each area, with three repetitions, at layers of $0-0.05 ; 0.05-0.10$; $0.10-0.20 ; 0.20-0.40 ; 0.40-0.60 ; 0.60-1.00 ; 1.00-1.50$ and $1.50-2.00 \mathrm{~m}$. For soil bulk density, undisturbed samples were collected at layers of $0-0.20$ and $0.20-0.40 \mathrm{~m}$. Compared with areas of native vegetation, soil bulk density values after 12 years increased by 25\% in Oxisols and 30\% in the Plinthic subgroups. In Oxisols and Plinthic subgroups, respectively, organic carbon concentration was, on average, $20.57,25.04 \mathrm{~g} \mathrm{~kg}^{-1}$ under native vegetation; 16.82, $16.59 \mathrm{~g} \mathrm{~kg}^{-1}$ after 3 years of no-tillage; 13.31, $4.96 \mathrm{~g} \mathrm{~kg}^{-1}$ after 8 years; $16.52,14.39 \mathrm{~g} \mathrm{~kg}^{-1}$ after 10 years; and 17.97, $18.53 \mathrm{~g} \mathrm{~kg}^{-1}$ after 12 years. In both soils, the no-tillage system contributed to an increase in carbon stocks over the years, but not at depth, being generally limited to the top $0.20 \mathrm{~m}$ of the soils. Compared to native vegetation, after 12 years of no-tillage, carbon stocks decreased at a rate of $0.075 \mathrm{Mg} \mathrm{ha}^{-1}$ year $^{-1}$ in the Plinthic subgroups and increased by $2.3 \mathrm{Mg} \mathrm{ha}^{-1}$ year $^{-1}$ in Oxisols.
\end{abstract}

Key words: conservationist agriculture, soil carbon stocks, bulk density, Oxisols, Plinthic subgroups

RESUMO: Objetivou-se neste estudo avaliar o efeito do plantio direto sobre a densidade do solo, o teor de carbono orgânico do solo e o estoque de carbono em Plintossolo Pétrico e Latossolo Vermelho-Amarelo (Oxisols), localizados no município de Pontes e Lacerda, no Estado de Mato Grosso, Brasil. Os tratamentos foram vegetação nativa e plantio direto de 3, 8, 10 e 12 anos. Para as análises de carbono orgânico do solo amostras de solo foram coletadas em cada área, com três repetições, nas camadas de $0-0,05 ; 0,05-0,10 ; 0,10-0,20 ; 0,20-0,40 ; 0,40-0,60 ; 0,60-1,00 ; 1,00-1,50$ e $1,50-2,00 \mathrm{~m}$. Para a densidade do solo foram coletadas amostras indeformadas em 0-0,20 e 0,20-0,40 m. Comparando-se com a vegetação nativa, os valores da densidade do solo aos 12 anos aumentaram $25 \%$ no Latossolo Vermelho-Amarelo e $30 \%$ no Plintossolo. No Latossolo e Plintossolo, respectivamente, os teores de carbono orgânico foram, em média, 20,57; $25,04 \mathrm{~g} \mathrm{~kg}^{-1}$ na vegetação nativa; 16,$82 ; 16,59 \mathrm{~g} \mathrm{~kg}^{-1}$ aos 3 anos de plantio direto; 13,$31 ; 4,96 \mathrm{~g} \mathrm{~kg}^{-1}$ aos 8 anos; 16,52 ; $14,39 \mathrm{~g} \mathrm{~kg}^{-1}$ aos 10 anos; e 17,97; 18,53 $\mathrm{g} \mathrm{kg}^{-1}$ aos12 anos. Em ambos os solos o plantio direto vem contribuindo para o aumento dos estoques de carbono ao longo dos anos, porém não em profundidade, limitando-se em geral até $0,20 \mathrm{~m}$. Comparados à vegetação nativa, aos 12 anos de plantio direto houve diminuição dos estoques de carbono a uma taxa de $0,075 \mathrm{Mg} \mathrm{ha}^{-1}$ ano $^{-1}$ no Plintossolo e um aumento de 2,3 $\mathrm{Mg} \mathrm{ha}^{-1}$ ano $^{-1}$ no Latossolo.

Palavras-chave: agricultura conservacionista, estoque de carbono, densidade do solo, Latossolo, Plintossolo

- Ref. 234803 - Received 06 Mar, 2020

* Corresponding author - E-mail: mapp@unemat.br

- Accepted 22 Dec, 2020 • Published 03 Feb, 2021

Edited by: Hans Raj Gheyi
This is an open-access article distributed under the Creative Commons Attribution 4.0 International License.

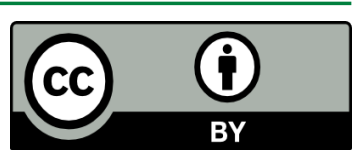




\section{INTRODUCTION}

Agriculture has been identified as one of the activities most responsible for the emission of carbon into the atmosphere, in the form of $\mathrm{CO}_{2}$. However, several studies (Cerri et al., 2004; FAO, 2017; Lal, 2018; Silva et al., 2018; Fernandes et al., 2018) show that agriculture can also act as a sink, sequestering $\mathrm{CO}_{2}$ from the atmosphere and storing it in soil organic matter.

In this context, management of the soil through conservationist cultivation systems is a strategy for reducing greenhouse gases emissions, since soil can store the carbon sequestered by biomass in the form of soil organic carbon (SOC) (Lal et al., 2018), representing an important emission reducing technology (Lal, 2019). This reinforces the need to use field surveys to monitor SOC stocks, mainly on a regional and local scale (FAO, 2017; Lal et al., 2018). Such studies are urgently required in the state of Mato Grosso, one of the largest areas of agricultural production in Brazil, but with few studies of this subject (Miranda et al., 2016; Bonini et al., 2018).

Cultivation in no-tillage (NT) systems enhances the soil's capacity to store SOC, in addition to increasing aggregate stability, water retention, and nutrient cycling, and reducing erodibility (Lal, 2004; Cerri et al., 2004). Studies indicate that Brazilian soils have the potential to sequester from 0.43 to 0.50 $\mathrm{Mg} \mathrm{ha}^{-1}$ year $^{-1}$ of SOC (Cerri et al., 2004). However, these values are low when considering the total loss of carbon resulting from the conversion of forest areas to soybean plantations in NT systems in Southwestern Amazonia, as reported by Bonini et al. (2018).

In this context, the objectives of this study were to evaluate soil bulk density (BD), SOC, and carbon stock (CS) in an area of intensive agriculture, cultivated under NT systems for different years ago, in the southwest region of Mato Grosso.

\section{Material AND Methods}

The study was carried out in a rural property located at $15^{\circ} 3^{\prime} 35.27^{\prime \prime} \mathrm{S}$ and $59^{\circ} 22^{\prime} 33.84^{\prime \prime} \mathrm{W}$ and at $252 \mathrm{~m}$ of altitude, in the municipality of Pontes e Lacerda, state of Mato Grosso, Brazil. The municipality is located in the hydrographic subbasin of the Guaporé River, part of the Amazon basin, in an ecotone area of the Amazon and Cerrado biomes (SEPLAN, 2011). According to the Köppen classification, the climate of the region is Aw - Savannah Equatorial with dry winter, with average annual precipitation of 1400 to $1600 \mathrm{~mm}$ and an average annual temperature from 24 to $25^{\circ} \mathrm{C}$ (maximum 33 and minimum $18^{\circ} \mathrm{C}$ ) (SEPLAN, 2011).

The study area is located in the Cenozoic Sedimentary Basin of Guaporé. The local geomorphology is characterized by a narrow strip of flat and shallow land (200-250 m) that extends along the southwestern border of the state, penetrating to the northwest into Bolivian territory, along the axis formed by the waters of the Guaporé River (SEPLAN, 2011). The regional geology is characterized by the presence of laterite detritic covers, the sedimentary metavolcanic sequence of the Jauru Plateau, and orthquartzitic and feldspathic meta-sandstones with conglomerate intercalation.
In the study area land use is focused on the production of grains and fibre, with some areas being used as pasture, as well as areas of native vegetation (NV). The crop areas are under notillage, which was implemented at different times. Previously, the crop areas were used as pasture, which has been gradually replaced by the cultivation of corn, soybean, and cotton crops.

In order to classify the soils, trenches were opened and a morphological description was carried out according to Santos et al. (2005), followed by collection of samples for laboratory analysis. Thus, the soils were classified (Santos et al., 2018) as Plinthic subgroups and Oxisols (United States Soil Survey Staff, 2014).

Granulometric analysis of the soils was determined using the pipette method (EMBRAPA, 2017): Oxisols presented a clay texture, while the Plinthic subgroups presented a sandyclay loam texture. Chemical soil fertility was determined using EMBRAPA (2017) methodologies. The soils in the study area showed adequate fertility at a layer of $0-0.20 \mathrm{~m}$, with no significant difference between NV and NTs that had been cultivated for different lengths of time, except that $\mathrm{P}$ concentrations were higher in cultivated areas. On average, the following values were obtained, respectively, for Oxisols and the Plinthic subgroups: $\mathrm{pH}$ of water, 5.9 and 6.0; $\mathrm{CTC}_{\mathrm{pH}} 8.2$ and $11 \mathrm{cmol}_{\mathrm{c}} \mathrm{dm}^{-3}$; base saturation (V): 65 and 72\%. Mean $\mathrm{P}$ contents were $4.9 \mathrm{mg} \mathrm{kg}^{-1}$ in NV, $12 \mathrm{mg} \mathrm{kg}^{-1}$ in Oxisols, and 29 $\mathrm{mg} \mathrm{kg}^{-1}$ in the Plinthic subgroups in cultivated areas.

As there is no official protocol for determining SOC, standardizing the number of plots to be sampled or the depths of sample collection, sampling was performed according to an adaptation of methodologies reported in the literature (Cerri et al., 2004; RAINFOR, 2014). For the determination of SOC, areas where NT was implemented in Oxisols and the Plinthic subgroups 3 (NT3), 8 (NT8), 10 (NT10), and 12 (NT12) years ago were selected, in addition to an area of $\mathrm{NV}$, constituting five treatments for each soil type. Three 1 ha plots were chosen for each treatment, within which soil samples were collected at layers of $0-0.05,0.05-0.10,0.10-0.20,0.20-0.40,0.40-0.60$, $0.60-1.00,1.00-1.50$, and 1.50-2.00 m, with repetition at five points in each plot to produce a composite sample. Due to the hardness of the material of the Plinthic subgroups, it was only possible to collect soil samples up to a depth of $1.0 \mathrm{~m}$ in these plots, while in Oxisols, collections were made to a depth of up to $2.0 \mathrm{~m}$.

Thus, the experimental design consisted of the soil class factors, Oxisols and Plinthic subgroups, NT implementation period (NT3), (NT8), (NT10) and (NT12), and depth of the soil profile, accompanied by a reference treatment of native forest vegetation $(\mathrm{NV})$, with 3 repetitions totalling 90 soil samples of the Plinthic subgroups and 120 samples of Oxisols. The soil samples were collected from April to July 2017.

To evaluate bulk density (BD) (EMBRAPA, 2017), soil samples were collected at layers of $0-0.20$ and $0.20-0.40$ m, using a Kopecky ring, in the same sample collection areas used for evaluation of soil organic carbon (SOC), totalling 60 undisturbed soil samples. Determination of SOC concentrations was by means of an elementary C analyser (CS cube, ElementarAnalisys ${ }^{\bullet}$ - Australia).

The EMBRAPA (2016) methodology was followed to calculate carbon stoke (CS), in which the equivalent soil 
mass was used, obtained from the $\mathrm{BD}$ values at a certain depth. In this study, CS was calculated to a depth of $1.0 \mathrm{~m}$ for both Oxisols and the Plinthic subgroups, because it was not possible to collect soil samples in the Plinthic subgroups at layers from 1.00-1.50 and 1.50-2.00 m. BD values from 0.20$0.40 \mathrm{~m}$ were also used to calculate CS at depths below 0.40 m because, according to Fialho \& Zinn (2014), common soil tillage operations rarely affect the soil structure below $0.40 \mathrm{~m}$.

To compare CS results between treatments and obtain the result over time, the rates of increase or decrease (CSr) were calculated according to Eq. 1

$$
\mathrm{CSr}=\frac{(\mathrm{CSf}-\mathrm{CSi})}{\mathrm{T}}
$$

where:

$\mathrm{CSr}$ - change in carbon stock, $\mathrm{Mg}$ ha year-1 ${ }^{-1}$, for each period of NT implementation;

CSf - average carbon stock at the final sampling time, $\mathrm{Mg} \mathrm{ha}^{-1}$;

CSi - average carbon stock at the initial sampling time, $\mathrm{Mg} \mathrm{ha}^{-1}$ (in this case, NV); and,

$\mathrm{T}$ - average time elapsed between treatments, referring to CSf and CSi, years.

The BD results and the SOC and CS concentrations were subjected to analysis of variance and the Scott-Knott test, at $\mathrm{p} \leq 0.05$, was used to analyse the differences between the means. Comparison of SOC data between soils was only performed to a depth of $1.0 \mathrm{~m}$, as it was not possible to sample to $2.0 \mathrm{~m}$ in the Plinthic subgroups soils. The software Sisvar 5.6 (Ferreira, 2011) was used for these analyses.

\section{Results AND Discussion}

Except in NT8, BD mean values did not vary significantly between soils $(\mathrm{p}>0.05)$ or depths $(\mathrm{p}>0.05)$, with $1.48 \mathrm{Mg}$ $\mathrm{m}^{-3}$ in the Oxisols and $1.56 \mathrm{Mg} \mathrm{m}^{-3}$ in the Plinthic subgroups, and $1.50 \mathrm{Mg} \mathrm{m}^{-3}$ for $0-0.20 \mathrm{~m}$ and $1.55 \mathrm{Mg} \mathrm{m}^{-3}$ for $0.20-0.40$ $\mathrm{m}$ samples. On the other hand, BD values varied significantly according to the duration of NT implementation ( $\mathrm{p} \leq 0.01$ ). It can be seen in Figure 1 that duration of NT cultivation increased $\mathrm{BD}$ to values considered to be restrictive to the development of root systems. For soybeans, for example, Silva et al. (2006) reported a decrease in the growth of the aerial part of the plants at BD values greater than $1.40 \mathrm{Mg} \mathrm{m}^{-3}$.

In the Plinthic subgroups, compared to NV, there was a $30 \%$ increase in BD from NT3 to NT12. The same change also occurred in Oxisols, except for a decrease in BD in NT8 compared to NT3, but the values return to values similar to those of NT3 in NT10 and NT12. In Oxisols, BD increased by $25 \%$, compared to NV, across all durations of NT. For both soils, values of BD increased when comparing NT and NV, which agrees with other studies (Silveira et al., 2008; Bertol et al., 2017). The effect of NT on BD, in this case, is negative, since an increase in $\mathrm{BD}$ indicates deterioration in soil structure due to compaction (Silveira et al., 2008), which impedes the infiltration of water into the soil and increases runoff, favouring erosion (Bertol et al., 2017).

Increased $\mathrm{BD}$ due to compaction, for example, can generate negative consequences (Silva et al., 2006; Bertol, 2017) regarding crucial factors in the context of SOC storage and the maintenance of soil health and safety (FAO, 2017). Although in this study BD increased with the period that soil was under cultivation. Caires et al. (2016) state that NT is the system that conserves soil best and, therefore, its adoption should be expanded in Brazil, despite the increase in BD. According to Caires et al. (2016), the key to maintaining soil quality under NT is the proper management of acidity and improvement of the root environment through the application of limestone and phosphogypsum, as this would improve rooting and reduce BD. In addition, Peixoto et al. (2020) concluded that problems related to NT, including soil compaction, can be minimized with the adoption of good management practices, such as the proper implementation of NT systems, crop diversification,

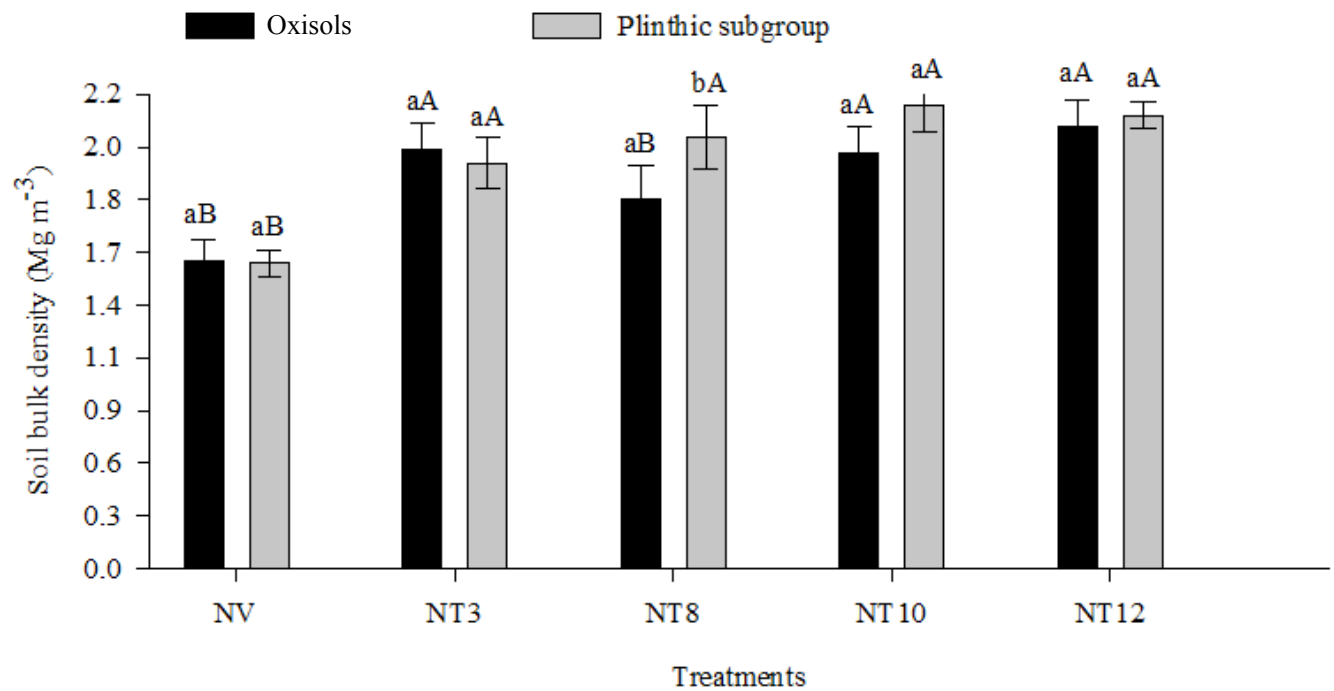

NV - Native vegetation; NT3 - Three years of no-tillage; NT8 - Eight years of no-tillage; NT10 - Ten years of no-tillage; NT12 - 12 years of no-tillage systems; Vertical bars represent standard error $(n=60)$; Different letters above the bars of the graph compare mean values (Scott Knott test, $\mathrm{p} \leq 0.05$ ); Lower case letters compare the soils with respect to no-tillage ages; uppercase letters compare no-tillage duration for each type of soil

Figure 1. Mean values of soil bulk density as a function of the duration of no-tillage (NT), Oxisols and Plinthic subgroups, in the southwest region of Mato Grosso, Brazil 
maintenance of soil cover, and control of machine traffic, always in conditions of adequate soil moisture.

In both soils, there was an effect of the ages of implementation of NT and the depth of collection of soil samples on SOC concentrations, without interaction between these factors. SOC concentrations did not vary significantly depending on the type of soil ( $\mathrm{p} \leq 0.05)$. Considering the duration that NT was implemented, the highest concentrations of SOC were found in NV and the lowest in NT8, as can be seen from Table 1. Regarding soil depth, the highest SOC concentrations were observed in the superficial layers (Table 1).

The highest SOC concentrations were found in the $0-0.20 \mathrm{~m}$ layer of NV, NT3, and NT8 and 0-0.10 m layer in NT10 and NT12, demonstrating that the increase in SOC has occurred over time under NT, but it is more superficial in the Plinthic subgroups (0-0.10 m). At the deepest layer, SOC concentrations in the Plinthic subgroups were higher in NV. Higher SOC concentrations in NV areas, compared to the other treatments, may be related to the presence of petroplinthites in the subsurface layers, preventing the root system from penetrating deeply, especially for annual crops. In addition, the consistency of these soils, medium to hard when dry, does not favour root system development, as observed during the morphological description of this soil profile.

In Oxisols, SOC concentrations were significantly lower for NT8 to $0.05 \mathrm{~m}$ when compared to other treatments at this depth, which were statistically similar to each other. At depths from $0.05-1.50 \mathrm{~m}$, there were no significant differences between treatments. However, from 1.50-2.00 m, mean SOC concentration were significantly higher in NV compared to all stages of NT implementation. SOC concentrations in Oxisols were equal at different ages of NT, except in NT8 at depths from 0-0.50 $\mathrm{m}$ and $1.50-2.00 \mathrm{~m}$, where concentration was higher under NV. This fact indicates that Oxisols under

Table 1. Mean organic carbon concentration in the soil (SOC) of Oxisols and the Plinthic subgroups at each depth and treatment, in areas under native vegetation (NV) and no-tillage (NT) for different durations in the southwest region of Mato Grosso, Brazil

\begin{tabular}{|c|c|c|c|c|c|}
\hline \multirow{3}{*}{$\begin{array}{l}\text { Depth } \\
\text { (m) }\end{array}$} & \multicolumn{5}{|c|}{ No-tillage duration } \\
\hline & NV & NT3 & NT8 & NT10 & NT12 \\
\hline & \multicolumn{5}{|c|}{$\left(\mathrm{g} \mathrm{kg}^{-1}\right)$} \\
\hline \multicolumn{6}{|c|}{ Oxisols } \\
\hline $0-0.05$ & $37.09 \mathrm{aA}$ & $34.47 \mathrm{aA}$ & $24.85 \mathrm{aB}$ & $32.12 \mathrm{aA}$ & $34.81 \mathrm{aA}$ \\
\hline $0.05-0.10$ & $28.94 \mathrm{bA}$ & $28.80 \mathrm{aA}$ & $21.56 \mathrm{aB}$ & $28.02 \mathrm{aA}$ & $28.79 \mathrm{aA}$ \\
\hline $0.10-0.20$ & $24.01 \mathrm{bA}$ & $24.42 \mathrm{bA}$ & $18.28 \mathrm{bA}$ & $21.02 \mathrm{bA}$ & $22.06 \mathrm{bA}$ \\
\hline $0.20-0.40$ & $20.48 \mathrm{cA}$ & $18.29 \mathrm{cA}$ & $15.01 \mathrm{bA}$ & $15.58 \mathrm{cA}$ & $18.42 \mathrm{cA}$ \\
\hline $0.40-0.60$ & $16.07 \mathrm{cA}$ & $12.56 \mathrm{dA}$ & $10.01 \mathrm{cA}$ & $11.08 \mathrm{cA}$ & $13.98 \mathrm{cA}$ \\
\hline $0.60-1.00$ & $13.98 \mathrm{cA}$ & $8.44 \mathrm{~dB}$ & $7.38 \mathrm{cB}$ & $8.93 \mathrm{cB}$ & $11.03 \mathrm{~dB}$ \\
\hline $1.00-1.50$ & $13.98 \mathrm{cA}$ & $6.41 \mathrm{eA}$ & $4.77 \mathrm{cA}$ & $8.28 \mathrm{cA}$ & $9.03 \mathrm{dA}$ \\
\hline $1.50-2.00$ & $15.53 \mathrm{dA}$ & $1.90 \mathrm{eB}$ & $4.63 \mathrm{cB}$ & $8.15 \mathrm{cB}$ & $5.67 \mathrm{~dB}$ \\
\hline Mean & $20.57 \mathrm{~A}$ & $16.91 \mathrm{~B}$ & $13.31 \mathrm{C}$ & $16.65 \mathrm{~B}$ & $17.97 \mathrm{~B}$ \\
\hline \multicolumn{6}{|c|}{ Plinthic subgroups } \\
\hline $0-0.05$ & $36.81 \mathrm{aA}$ & $32.48 \mathrm{aA}$ & $10.46 \mathrm{aB}$ & $29.90 \mathrm{aA}$ & $31.66 \mathrm{aA}$ \\
\hline $0.05-0.10$ & $32.24 \mathrm{aA}$ & $31.27 \mathrm{aA}$ & $8.57 \mathrm{aB}$ & $26.88 \mathrm{aA}$ & $28.51 \mathrm{aA}$ \\
\hline $0.10-0.20$ & $28.13 \mathrm{aA}$ & $27.21 \mathrm{aA}$ & $6.68 \mathrm{aC}$ & $17.02 \mathrm{bB}$ & $22.37 \mathrm{bA}$ \\
\hline $0.20-0.40$ & $24.58 \mathrm{bA}$ & $20.02 \mathrm{bA}$ & $3.16 \mathrm{aB}$ & $15.50 \mathrm{bA}$ & $19.17 \mathrm{bA}$ \\
\hline $0.40-0.60$ & $22.93 \mathrm{bA}$ & $12.83 \mathrm{cB}$ & $2.30 \mathrm{aC}$ & $10.08 \mathrm{bB}$ & $18.77 \mathrm{bA}$ \\
\hline $0.60-1.00$ & $18.55 \mathrm{bA}$ & $6.65 \mathrm{cB}$ & $1.94 \mathrm{aB}$ & $7.20 \mathrm{bB}$ & $11.61 \mathrm{bA}$ \\
\hline Mean & $27.21 \mathrm{~A}$ & $21.74 \mathrm{~B}$ & $5.52 \mathrm{D}$ & $17.76 \mathrm{C}$ & $22.02 \mathrm{~B}$ \\
\hline
\end{tabular}

Lower case letters compare the depth that soil was sampled at each no-tillag implementation duration; Uppercase letters in the row compare no-tillage ages; NT3: No-tillage for 3 years; NT8: No-tillage for 8 years; NT: No-tillage for 10 years; NT12: No-tillage for 12-years
NT maintains SOC concentrations throughout the period of cultivation, as seen in NV. This finding is important, as it attests that, under the conditions of this study, the cultivation system adopted maintains soil functionality related to SOC levels in Oxisols, as pointed out by Lal (2004).

As for SOC concentrations along the sampling depths, in Oxisols in NT areas, SOC concentrations were significantly higher in the $0-0.10 \mathrm{~m}$ layer, and in general, they gradually decreased to $2.00 \mathrm{~m}$ (Table 1). In Oxisols under NV, there was an increase in SOC concentrations of about $50 \%$ in the 1.50 $2.00 \mathrm{~m}$ layer in relation to the $1.00-1.50 \mathrm{~m}$ layer, which may be associated with the presence of roots at this layer.

In the Plinthic subgroups (Table 1) up to $0.40 \mathrm{~m}$, SOC concentrations were significantly lower for NT8 when compared to the other treatments, which were similar to each other; from 0.40-1.00 m, SOC concentrations differed between treatments, with statistically significant and consecutive decreases in the concentrations from NV to NT8. From NT8 onwards, SOC concentrations rose, equalling NV at NT12. At depths of 0.40-0.60 m, SOC levels were lower for NT3 and NT8.

In both Oxisols and the Plinthic subgroups (Table 1), SOC concentrations decreased until NT8 in comparison to NV and then increased in NT10 and NT12 before reaching values close to NV. These values for SOC concentration remained in the more superficial layers of the soil, as can be seen in Table 1 This finding shows a negative $\mathrm{C}$ emission, in agreement with that reported by Lal (2019), showing that NT favours the maintenance of SOC.

At a layer of $0.10-0.20 \mathrm{~m}$ the soils in the present study had higher SOC concentrations than those found in studies by Bonini et al. (2018), in an area that had been and soybean plantations since 2003, showing that it is not possible to generalize about the capacity of a given cultivation system or an area under forest to store SOC. Regarding depth, these results corroborate studies cited by Powlson et al. (2016), whose values showed that near the soil surface, in NT, there is a considerable increase in SOC concentration, which does not occur at greater depth.

CSs varied significantly according to depth $(\mathrm{p} \leq 0.01)$ and duration of NT cultivation ( $\mathrm{p} \leq 0.01$ ), as found for SOC. Figure 2 shows the CSs for both soils to a depth of $2 \mathrm{~m}$ in Oxisols and $1 \mathrm{~m}$ in the Plinthic subgroups, as well as the annual rates of decline of SOC for each duration of NT implementation. It may be observed that the CSs are higher in Oxisols. However, in both soils, there was a decline in CSs associated with the duration of NT implementation, more pronounced until NT8, with a subsequent decrease of this decline until NT12. In NT12, the CS was practically equal to the NV in both soils (Figure 2), with a reversal of the decline in SOC in Oxisols (Figure 2B). This fact is probably due due to the greater accumulation of straw over time in NT, restoring the balance between SOC output and input (Lal, 2004), as well as the higher mineralization of soybeans residues.

Comparing NT12 and NV, it was observed that in 12 years of NT, CS was lost at a rate of $-0.075 \mathrm{Mg} \mathrm{ha}^{-1}$ year-1 $^{-1}$ in the Plinthic subgroups (Figure 2). On the other hand, in the Oxisols, in the same period, there was a gain in CS equivalent to $2.3 \mathrm{Mg} \mathrm{ha}^{-1}$ year $^{-1}$. According to Lal et al. (2018), a positive SOC balance 

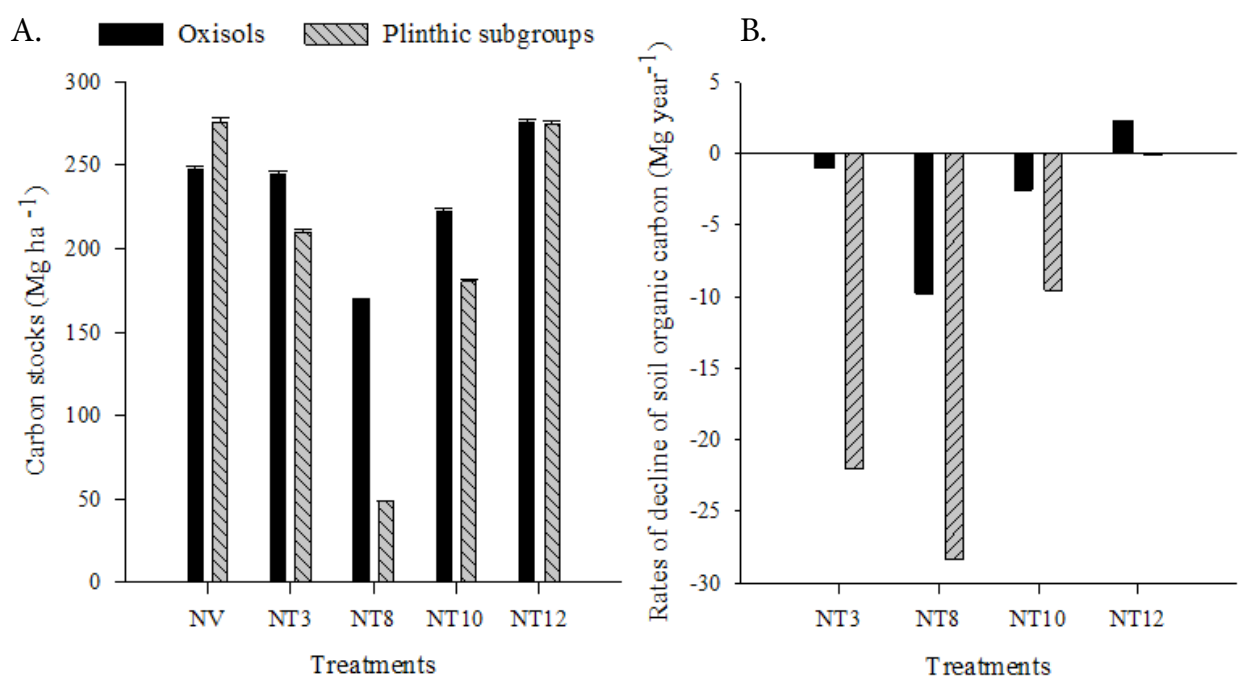

NV - Native vegetation; NT3 - Three years of no-tillage; NT8 - Eight years of no-tillage; NT10 - Ten years of no-tillage; NT12 - 12 years of no-tillage systems

Figure 2. Carbon stocks (CS) of Oxisols and Plinthic subgroups (A) and rates of decline (B) of SOC in an area under no-tillage (NT) for different durations in the southwest region of Mato Grosso, Brazil

means that biomass input exceeds losses caused by erosion, mineralization, and leaching, indicating that soil management is contributing to a reduction in $\mathrm{CO}_{2}$ emissions. It is noteworthy, however, as can be seen in Figure 2, that there was a downward trend in SOC loss over the years of NT implementation.

Beyond contributing to the mitigation of greenhouse gases, SOC is fundamental to the health and quality of the soil (Cardoso et al., 2013), which is essential for the maintenance of its ecosystem functions and services. Thus, a decline in SOC potentiates soil degradation affecting food, water, and climate security. This reinforces the need to monitor SOC stocks, mainly on a regional and local scale (Fernandes et al., 2018; Silva et al., 2018), obtained by field surveys (FAO, 2017; Lal et al., 2018).

The higher rate of decrease in SOC in the Plinthic subgroups compared to Oxisols may be associated with differences in texture between soil types, given that the textural classification of Oxisols samples was clayey, while in the Plinthic subgroups it was sandy-clay, which may have influenced the adsorption and protection of the SOC and, consequently, of the CS (Fialho \& Zinn, 2014).

Several studies have demonstrated NT systems' ability to increase SOC concentration, increasing the CS (Cerri et al., 2004; Miranda et al., 2016) of soil. On the other hand, others have shown decrease in CS due to the implementation of NT (Ferreira et al., 2016). In this context, the adoption of NT systems promotes an estimated increase in SOC levels in tropical and temperate soils of $0.33 \pm 0.11 \mathrm{Mg} \mathrm{ha}^{-1} \mathrm{yr}^{-1}$ (Six et al., 2002), a fact that results in increased soil resilience and agronomic productivity, as shown by the studies of Sá et al. (2014). It is worth mentioning that many of these studies were conducted under different conditions: periods of adoption of NT, previous land use conditions, soil types, crop rotations, fertilizer applications, sampling methods and methods to determine CS, which is reflected in the difficulties and uncertainties in comparisons of the results reported in the literature. In addition, soils in general have widely variable attributes (Araújo et al., 2018) that certainly influence the results of SOC in all biomes.

\section{Conchusions}

1. The values of soil bulk density increased with the duration of no-tillage systems implementation, by around $25 \%$ in Oxisols, and $30 \%$ in the Plinthic subgroups, compared to areas of native vegetation.

2. In Oxisols and Plinthic subgroups soils, the conversion of areas of native vegetation to agriculture reduced the soil organic carbon, but it recovered after 10 years of no-tillage cultivation.

3. After 12 years of no-tillage, stocks of organic carbon in the soil decreased at a rate of $0.075 \mathrm{Mg} \mathrm{ha}^{-1} \mathrm{yr}^{-1}$ in the Plinthic subgroups and increased by $2.3 \mathrm{Mg} \mathrm{ha}^{-1} \mathrm{yr}^{-1}$ in Oxisols, compared to the area of native vegetation.

4. Increased duration of implementation of no-tillage resulted in a decrease in the rates of reduction of carbon stocks in both soils.

\section{ACKnowledgments}

Sincere thanks to the Coordenação de Aperfeiçoamento de Pessoal de Nível Superior (CAPES) for the granting of scholarships to the first author for a Master's Degree in Environmental Sciences at the Universidade do Estado de Mato Grosso (UNEMAT) and to the Fundação de Amparo à Pesquisa do Estado de Mato Grosso (FAPEMAT) for granting a scholarship to the Scientific Initiations students who helped with the research.

\section{Literature Cited}

Araújo, D. C. dos S.; Montenegro, S. M. G. L.; Montenegro, A. A. de A.; Silva Junior, V. de P. e; Santos, S. M. dos. Spatial variability of soil attributes in an experimental basin in the semi-arid region of Pernambuco, Brazil. Revista Brasileira de Engenharia Agrícola e Ambiental, v.22, p.38-44, 2018. https://doi.org/10.1590/18071929/agriambi.v22n1p38-44

Bertol, I.; Luciano, R. V.; Bertol, C.; Bagio, B. Nutrient and organic carbon losses, enrichment rate, and cost of water erosion. Revista Brasileira de Ciência do Solo, v.41, p.1-15, 2017. https://doi. org/10.1590/18069657rbcs20160150 
Bonini, I.; Marimon-Júnior, B.H.; Matricardi, E.; Phillips, O.; Petter, F.; Oliveira, B.; Marimon, B. S. Collapse of ecosystem carbon stocks due to forest conversion to soybean plantations at the Amazon-Cerrado transition. Forest Ecology and Management, v.414, p.64-73, 2018. https://doi.org/10.1016/j.foreco.2018.01.038

Caires, E. F.; Zardo Filho, R.; Barth, G.; Joris, H. A. W. Optimizing nitrogen use efficiency for no-tillage corn production by improving root growth and capturing $\mathrm{NO}_{3}{ }^{-}$in subsoil. Pedosphere, v.26, p.474-485, 2016. https://doi.org/10.1016/S1002-0160(15)60058-3

Cardoso, E. J. B. N.; Vasconcellos, R. L. F.; Bini, D.; Miyauchi, M. Y. H.; Santos, C. A. dos; Alves, P. R. L.; Paula, A. M. de; Nakatani, A. S.; Pereira, J. de M.; Nogueira, M. A. Soil health: looking for suitable indicators. What should be considered to assess the effects of use and management on soil health? Scientia Agricola, v.70, p.274289, 2013. https://doi.org/10.1590/S0103-90162013000400009

Cerri, C. C.; Bernoux, M.; Cerri, C. E. P.; Feller, C. Carbon cycling and sequestration opportunities in South America: the case of Brazil. Soil Use and Management, v.20, p.248-254, 2004. https:// doi.org/10.1079/SUM2004237

EMBRAPA - Empresa Brasileira de Pesquisa Agropecuária. Protocolo para avaliar o potencial de sistemas agrícolas no sequestro de $C$ e acúmulo de N no solo. Embrapa Agrobiologia. Seropédica, RJ, 2016. 23p.

EMBRAPA - Empresa Brasileira De Pesquisa Agropecuária. Manual de métodos de análise de solo. 3. ed. Brasília, DF. 2017. 573p.

FAO - Food and Agriculture Organization of the United Nations. Soil organic carbon: The hidden potential, 2017a. Available at: < http://www.fao.org/3/a-i6937e.pdf >. Accessed: August 2017.

Ferreira, D. F. Sisvar: A computer statistical analysis system. Ciência e Agrotecnologia. v.35, p.1039-1042, 2011. https://doi.org/10.1590/ S1413-70542011000600001

Ferreira, E. A. B.; Bustamante, M. M. da C.; Resck, D. V. S.; Figueiredo, C. C.; Pinto, A. de S.; Malaquias, J. V. Carbon stocks in compartments of soil organic matter 31 years after substitution of native Cerrado vegetation by agroecosystems. Revista Brasileira de Ciência do Solo, v.40, p.1-15, 2016. https:// doi.org/10.1590/18069657rbcs20150059

Fernandes, C. de A. F.; Matsumoto, S. N.; Fernandes; V. S. Carbon stock in the development of different designs of biodiverse agroforestry systems. Revista Brasileira de Engenharia Agrícola e Ambiental, v.22, p.720-725, 2018. https://doi.org/10.1590/18071929/agriambi.v22n10p720-725

Fialho, R. C.; Zinn, Y. L. Changes in soil organic carbon under eucalyptus plantations in Brazil: A comparative analysis. Land Degradation \& Development, v.25, p.428-437, 2014. https://doi. org/10.1002/ldr.2158

Lal, R. Soil carbon sequestration impacts on global climate change and food security. Science. v.304, p.1623-1627, 2004. https://doi. org/10.1126/science.1097396

Lal, R. Conceptual basis of managing soil carbon: inspired by nature and driven by science. Journal of Soil and Water Conservation, v.74, p.29A-34A, 2019. https://doi.org/10.2489/jswc.73.6.145A

Lal, R.; Smith, P.; Jungkunst, H. F.; Mitsch, W. J.; Lehmann, J.; Ramachandran Nair, P. K.; McBratney, A. B.; Sá, J. C. de M.; Schneider, J.; Zinn, Y. L.; Skorupa, A. L. A.; Zhang, H-L.; Minasny, B.; Srinivasrao, C.; Ravindranath, N. H. The carbon sequestration potential of terrestrial ecosystems. Journal of Soil and Water Conservation, v.73, p.145A-152A, 2018. https://doi.org/10.2489/ jswc.73.6.145A
Miranda, E.; Carmo, J.; Couto, E.; Camargo, P. Long-term changes in soil carbon stocks in the Brazilian Cerrado under commercial soybean. Land Degradation and Development, v.27, p.1586-1594, 2016. https://doi.org/10.1002/ldr.2473

Peixoto, D. S.; Silva, L. de C. M. da; Melo, L. B. B. de; Azevedo, R. P.; Araújo, B. C. L.; Carvalho, T. S. de; Moreira, S. G.; Curi, N.; Silva, B. M. Occasional tillage in no-tillage systems: a global meta-analysis. Science of the Total Environment, v.745, p.1-14, 2020. https://doi. org/10.1016/j.scitotenv.2020.140887

Powlson, D. S.; Stirling, C. M.; Thierfelder, C.; White, R. P.; Jat, M. L. Does conservation agriculture deliver climate change mitigation through soil carbon sequestration in tropical agro-ecosystems? Agriculture, Ecosystems \& Environment, v.220, p.164-174, 2016. https://doi.org/10.1016/j.agee.2016.01.005

RAINFOR - Rede Amazônica de Inventários Florestais. Protocolo RAINFOR para coleta de solos. 2014. Available at: <http://www. rainfor.org/upload/ManualsSpanish/COLECTA\%20DE\%20 MUESTRAS\%20DE\%20SUELO_2014_2.pdf>. Accessed:October 2016.

Sá, J. C. de M.; Tivet, F.; Lal, R.; Briedis, C.; Hartman, D. C.; Santos, J. Z. dos; Santos, J. B. dos. Long-term tillage systems impacts on soil C dynamics, soil resilience and agronomic productivity of a Brazilian Oxisols. Soil and Tillage Research, v.136, p.38-50, 2014. https://doi.org/10.1016/j.still.2013.09.010

Santos, H. G. dos; Jacomine, P. K. T.; Anjos, L. H. C. dos; Oliveira, V. A. de; V.; Lumbreras, J. F.; Coelho, M. R.; Almeida, J. A. de; Oliveira, J. B.; Cunha, T. J. F. Sistema brasileiro de classificação de solos. 5. ed. Brasília, DF: Embrapa, 2018. 323p.

Santos, R. D.; Lemos, R. C.; Santos, H. G.; Ker, J. C.; Anjos, L. H C. Manual de descrição e coleta de solo no campo. Sociedade Brasileira de Ciência do Solo, 5. ed. Viçosa, MG. 2005, 100p.

SEPLAN - Secretaria de Estado de Planejamento e Coordenação Geral. Atlas de Mato Grosso: abordagem socioeconômicoecológica. 2011. Available at: <http://www.seplan.mt.gov. $\mathrm{br} /$ documents/363424/3720413/Livro+Atlas+2011+web. pdf/24de2006-fd58-4171-a9e7-ee7f948f0a76>. Accessed: November 2016.

Silva, G. J.; Maia, J. C. de S.; Bianchini, A. Crescimento da parte aérea de plantas cultivadas em vaso, submetidas à irrigação subsuperficial e a diferentes graus de compactação de um Latossolo Vermelho-Escuro distrófico. Revista Brasileira de Ciência do Solo, v.30, p.31-40, 2006. https://doi.org/10.1590/ S0100-06832006000100004

Silva, J. C. N.; Silva, A. R.; Veloso, C. A. C.; Dantas, E. F.; Sacramento, J. A. A. S. do. Aggregation, carbon, and total soil nitrogen in crop-livestock-forest integration in the Eastern Amazon. Revista Brasileira de Engenharia Agrícola e Ambiental, v.22, p.837-842, 2018. https://doi.org/10.1590/1807-1929/agriambi. v22n12p837-842

Silveira, P. M. da; Stone, L. F.; Alves Junior, J.; Silva, J. G. da. Efeitos do manejo do solo sob plantio direto e de culturas na densidade e porosidade de um latossolo. Bioscience Journal, v.24, p.53-59, 2008.

Six, J.; Feller, C.; Denef, K.; Ogle, S. M.; Sa, J. C. de M.; Albrecht, A. Soil organic matter, biota and aggregation in temperate and tropical soils - effects of no-tillage. Agronomie, v.22, p.755-775, 2002. https://doi.org/10.1051/agro:2002043

United States Soil Survey Staff. Keys to soil taxonomy. 12. ed. Washington, DC: United States Department of Agriculture, Natural Resources Conservation Service; 2014. 372p. 